\title{
STUDI FENOMENOLOGI : PENGALAMAN PSIKOLOGIS MANTAN PEROKOK DALAM MENGHENTIKAN KEBIASAAN MEROKOK DI KOTA BUKITTINGGI
}

\author{
Silvia Intan Suri, Hema Malini \\ Fakultas Keperawatan, Universitas Andalas \\ Jln. Mr. Asaat 46b Kecamatan Mandiangin Koto Selayan Bukittinggi \\ email: intan.yumnamazaya@gmail.com
}

\begin{abstract}
Based on some experience of smokers, smoking habit can be stopped in some time. However, not all that successful in stopping the habitin a long period of time. Still a little research to see how the experience of the former smokers who successfully stopped smoking habit. This research aims to explore in depth the psychological experience of former smokers in stopping smoking habit. This research uses qualitative research methods with the phenomenology of approach. Data obtained with the in-depth interview against 5 persons participating which have variation in the length of time it has managed to stop smoking. Research results get some major aspect of the successful. Response smokers in quitting smoking; the obstacles they face, the mechanism of motivation and koping used in stop smoking habit, and the changes to be felt after quitting. This research managed to identify some important aspects such as the strategies used and the underlying motivation to stop smoking. Expected results of this research can be an input for smokers or health workers in providing support so that smokers can quit their habits for long periods of time or permanently.
\end{abstract}

Keywords: Experiences, Psychological, Former smoker

\section{PENDAHULUAN}

Berdasarkan dari beberapa hasil penelitian diperkirakan bahwa pada tahun 2030 akan ada 8 juta kematian terkait rokok per tahun di dunia. Merokok merupakan salah satu faktor utama resiko pada kanker paru-paru, penyakit pernafasan kronis, penyakit jantung koroner, stroke. Menurut Lee, Oxon, Thornton, Forey, \& Hamling (2017) menyatakan dari paparan lingkungan asap rokok; perokok dan mantan perokok akan beresiko terjadi stroke $(20 \%-30 \%)$, dan $15 \%$ menambah keparahan bronkhitis pernafasan pada perokok (Sayiner et al., 2013). Yingying et al (2016)

Perilaku merokok selain berpengaruh terhadap kesehatan, juga berpengaruh pada aspek psikologis yaitu mengacu kepada pikiran, perasaan dan perilaku. Pengaruh pada aspek psikologis dari rokok/ tembakau memberi stimulasi, seperti depresi ringan, gangguan daya tangkap, alam perasaan, alam pikiran, tingkah laku, dan fungsi psikomotor. Misalnya, kurang energi, egois, frustasi, kegugupan, konsentrasi rusak, pusing, mengantuk, kelelahan, insomnia, detak jantung tidak teratur, berkeringat, ketagihan rokok, perasaan bersalah, isolasi sosial, depresi (Brandt et al., 2017).

Giannakopoulos et al (2012) bahwa jika perokok berhenti merokok akan mengalami gejala-gejala seperti mudah tersinggung, gelisah, mudah cemas, gugup, kesadaran dan perhatian menurun, gangguan tidur, dan cepat lapar. Gejala-gejala ini bisa terjadi setelah beberapa jam seseorang berhenti merokok, sehingga inilah yang menyebabkan seseorang kembali merokok dalam waktu singkat. Gejala-gejala ini mencapai puncaknya pada hari-hari awal ketika berhenti merokok, dan mungkin mereda dalam beberapa minggu. Namun bagi sebagian orang, gejala ini akan tetap bertahan selama berbulan-bulan.

Menurut Hughes et al (2014) mengatakan bahwa kekambuhan tertinggi biasanya terjadi dalam beberapa minggu pertama, diantaranya $(75 \%)$ dari mantan perokok berupaya untuk berhenti. $95 \%$ dari mantan perokok gagal dalam mempertahankan untuk tidak merokok yang terjadi dalam waktu satu tahun pertama. Hawkins et al (2010) melakukan penelitian pada para mantan perokok didapatkan hasil bahwa keinginan untuk kembali merokok akan tetap ada, walaupun mereka telah berhenti merokok bertahun-tahun lamanya. Maka dari itu butuh niat yang sangat kuat untuk bisa menghentikannya, serta perlu ada pengendalian diri, sehingga keinginan untuk tidak merokok tercapai (Tombor et al., 2015)

Yingying et al (2016) menyatakan ada berbagai macam alasan untuk bisa berhenti merokok. Dimana $81,91 \%$ dari perokok berhenti dengan alasan kesehatan; 61,63\% dari perokok dengan tingkat 
pendidikan lebih akan mudah untuk berhenti merokok; 50,27\% dari perokok berhenti merokok dengan alasan karena teman/ iklan/ media sosial. Hasil Global Youth Tobacco Survey (GYTS) (2014) menunjukkan bahwa $71,3 \%$ dari perokok berhenti karena peringatan pada bungkus rokok. Penelitian Siriwong (2015) menyatakan bahwa perilaku berhenti merokok lebih tinggi ditemukan pada mereka yang mempunyai tingkat pendidikan tinggi, mempunyai dukungan keluarga yang tinggi, dan kebiasaan merokok yang tidak terlalu lama. Penelitian Abdulla (2015) menemukan bahwa kebiasaan merokok bisa berhenti jika ada kebijakan dari perusahaan untuk melarang merokok. Penelitian ini juga menemukan bahwa kegagalan atau kambuh kembali untuk merokok dikarenakan pengaruh sesama rekan kerja.

Penelitian Tulloch et al (2016) bahwa kesehatan sebanyak (91\%) adalah motivasi yang paling umum ditemukan pada mantan perokok untuk berhasil dalam usaha berhenti merokok. Ditemukan dukungan keluarga/ sosial $(28,1 \%)$ dan motivasi dari ekonomi (27,9\%). Penelitian Khattab et al (2016) pada tentara yang perokok di Khairo menyatakan $(99,82 \%)$ perokok akan berhenti merokok karena penyakit serius. Selain itu alasan lain perokok berhenti dari kebiasaan merokok untuk mencari gaya hidup yang sehat.

Berdasarkan data The Tobacco Atlas (2015), Indonesia menempati urutan pertama dunia untuk jumlah pria perokok di atas usia 15 tahun. Berdasarkan Survey Sosial Ekonomi Nasional (Susenas) oleh Badan Pusat Statistik (BPS) (2015), prevalensi perokok di Indonesia tercatat (31\%) dari jumlah penduduk. Dimana prevalensi perokok lelaki (60-65\%), sedangkan perokok perempuan (1-2\%). Laporan Riskesdas (2013) di Provinsi Sumatera Barat menempati urutan ke 6 perokok terbanyak di Indonesia mencapai (30.3\%).

Penelitian ini ingin mengekplorasi secara lebih dalam tentang makna gambaran pengalaman para mantan perokok dalam proses berhenti merokok sampai akhirnya mereka berhasil. Penelitian ini dapat memberikan informasi bagaimana para perokok menjalani proses berhenti merokok, makna dari proses tersebut, sehingga diharapkan dapat menjadi masukan penting bagi para perokok dan juga dalam pengembangan program untuk berhenti merokok.

\section{METODE PENELITIAN}

Penelitian ini menggunakan metode penelitian kualitatif dengan pendekatan fenomenologi. Terdapat lima partisipan dalam penelitian ini yang cukup heterogen. Partisipan dalam penelitian ini mewakili mereka yang perokok ringan dan berat dengan lama berhenti merokok dari 6 bulan sampai lebih dari 10 tahun. Partisipan dalam penelitian ini memenuhi kriteria inklusi sebagai berikut : (1) partisipan sudah berhenti merokok, minimal enam bulan sebelum pengambilan data. (2) Partisipan pernah merokok tetap dan tergolong tipe perokok berat (21-31) batang perhari atau lebih). (3) Partisipan bersedia diwawancarai dan direkam percakapannya.

Kriteria ekslusi partisipan adalah partisipan yang mengundurkan diri menjadi responden. Pekerjaan partisipan yaitu wiraswasta bervariasi : pensiunan, mahasiswa, pegawai, polisi. Metode pengambilan partisipan dengan metode porpusive sampling, dimana peneliti memilih partisipan dengan pertimbangan yang berdasarkan kriteria dan tujuan penelitian.

Cara pemilihan partisipan ini tidak diarahkan pada jumlah tetapi berdasarkan pada asas kesesuaian dan kecukupan sampai saturasi data. Metode analisa data Collaizi dalam mengolah data hasil wawancara mendalam pada partisipan. Proses analisa di mulai dengan penentuan kata kunci, dilanjutkan dengan penentuan kategori, sub tema dan terakhir adalah penentuan tema. Partisipan pada penelitian ini berjumlah lima orang, karena pada partisipan kelima sudah mengalami saturasi data.

\section{HASIL DAN PEMBAHASAN}

Karakteristik Partisipan

Usia partisipan bervariasi, usia termuda 19 tahun dan tertua 65 tahun. Semua partisipan berstatus perokok berat dengan rata-rata menghisap $>20$ batang/ hari. Semua partisipan rata-rata lama (durasi) berhenti merokok lebih dari 6 bulan, durasi berhenti merokok paling singkat 8 bulan dan durasi paling lama berhenti merokok 17 tahun. Semua partisipan memiliki pekerjaan yang bervariasi yaitu pensiunan, mahasiswa, pegawai, polisi.

Penelitian ini berhasil mengidentifkasi beberapa aspek penting dari para mantan perokok baik dari segi respon secara kognitif, afektif dan psikomotor; hambatan yang dihadapi dalam upaya berhenti merokok; mekanisme koping dan motivasi yang digunakan dalam menghentikan kebiasaan merokok; dan perubahan yang dirasakan setelah berhenti merokok.

1. Respon dalam berhenti merokok

Usaha untuk berhenti merokok sampai akhirnya seorang perokok berhasil menghentikan kebiasaan merokok mempunyai pengaruh terhadap diri perokok. Ada beberapa aspek yang mengalami perubahan 
dalam upaya berhenti merokok, yaitu: kognitif, afektif, dan psikomotor. Pada respon secara kognitif, seorang perokok akan mempunyai persepsi yang berbeda dalam upaya berhenti merokok. Mengubah persepsi terhadap rokok merukapakan sebuah ancaman dan sebagai sumber penyakit berhasil dalam membantu upaya berhenti merokok. Respon yang ditemukan dari ungkapan seperti persepsi tentang merokok, persepsi tentang ancaman dan persepsi tentang penyakit. Dalam penelitian ini berbagai macam bentuk persepsi tentang merokok yang ditemukan. Mantan perokok menyatakan bahwa merokok merupakan perilaku yang tidak bagus, perilaku yang hanya memasukkan penyakit kedalam tubuh, perilaku membuang uang, merokok juga tidak memiliki manfaat dari segi kesehatan dan materi. Seperti ungkapan "sebenarnya tidak ada manfaat nya, tidak ada gunanya, mungkin secara materi saya sudah rugi, dari segi kesehatan saya rugi. Bisa kanker paru nantinya"(P2). Dari ungkapan mantan perokok menunjukkan bahwa mantan perokok mengalami perubahan secara kognitif terhadap merokok dan bahaya yang di timbulkan dari perilaku merokok.

Berdasarkan wawancara pada penelitian ini, sebagian partisipan mengungkapkan bahwa pengetahuan akan bahya yang ditimbulkan dari perilaku merokok sudah diketahui sebelum mantan perokok berhenti merokok. Namun berbagai alasan, maka pengetahuan akan bahaya yang ditimbulkan dari perilaku merokok dikesampingkan. Namun hal ini juga tidak disertai dengan niat kuat dan motivasi lainnya yang bisa mendorong untuk berhenti merokok.

Sebagian mantan perokok mengungkapkan bahwa tidak mengetahui akan bahaya yang ditimbulkan dari perilaku merokok. Namun setelah mantan perokok mengalami penyakit yang yang ditimbulkan akibat dari merokok, maka beberapa mantan perokok mencari tau informasi tentang bahaya rokok bagi kesehatan. Sehingga mantan perokok memutuskan untuk berhenti merokok. Maka secara kognitif terjadi perubahan pengetahuan akan bahaya yang di alami mantan perokok.

Penelitian Syafiie (2009) menyatakan bahwa perokok akan merubah perilaku merokok apabila memiliki pengetahuan, dimana perilaku merokok berdampak buruk dari berbagai aspek. Dengan adanya pengetahuan, perokok berusaha merubah perilaku dari merokok menjadi berhenti merokok dengan mengetahui sifat atau keadaan yang menyebabkan merokok.

Berbagai macam persepsi dan pandangan terhadap perilaku merokok yang berkaitan dengan pengetahuan yang dimiliki oleh mantan perokok dalam berhenti merokok. Respon kognitif didapat oleh mantan perokok didapat dari berbagai sumber yang ada. Seperti iklan, media massa, maupun pengetahuan dari orang sekitar mantan perokok.

Selain alasan menjaga kesehatan, berbagai alasan lain yang ditemukan mantan perokok untuk berhenti merokok. Sebahagian besar perokok berhenti merokok karena lingkungan dan faktor keadaan fisik yang tidak memungkinkan mantan perokok untuk merokok. Hal tersebut membuat mantan perokok merubah perilaku kearah yang lebih baik. Sesuai dengan metode berhenti merokok yang selama ini yang dikembangkan oleh para ahli dalam (Syafiie, 2009) bahwa cognitive behavioral therapy dengan kesadaran akan perilaku menjadi dasar untuk merubah perilaku kearah yang diinginkan.

Dari segi respon afektif, teridentifikasi adanya respon berupa perasaan cemas, takut dan merasa canggung ketika tidak merokok. Respon afektif yaitu respon yang dirasakan oleh mantan perokok yang berkaitan dengan perasaan emosional dalam usaha berhenti merokok.

Perasaan takut yang dirasakan oleh mantan perokok, berupa rasa takut akan penyakit yang ditimbulkan oleh rokok, seperti ." Ada perasaan takut bisa kanker paru bila kembali merokok. Sudah terbayang penyakit, takut rasanya"(P2). Dari pernyataan tersebut menunjukkan bahwa mantan perokok memiliki perasaan takut akan penyakit yang ditimbulkan apabila kembali merokok. Ungkapan lain ada rasa takut akan ancaman dari istri dan kedua orang tua partisipan, Ungkapan ini muncul karena partisipan dalam berhenti merokok, karena pengaruh ancaman dari keluarga.

Selain itu, respon afektif yang di rasakan oleh mantan perokok juga muncul dari perasaan cemas. Partisipan mengungkapan cemas akan memperburuk kondisi kesehatan bila kembali merokok. Seperti ungkapan ".....ada perasaan cemas, batuk ini tidak juga kunjung sembuh". Ungkapan tersebut menunjukkan bahwa perasaan cemas dirasakan oleh mantan perokok bila kembali merokok akan memperburuk penyakit yang di alami mantan perokok.

Perasaan canggung yang juga di alami mantan perokok, yang mengungkapkan bahwa mantan perokok merasakan canggung saat berhenti merokok karena terbiasa memegang rokok. Dari ungkapan mantan perokok menunjukkan bahwa perasaan canggung muncul dari respon yang dirasakan akibat kebiasaan yang sulit hilang saat sebelum berhenti merokok.. Selain itu mantan perokok juga menjadikan rokok sebagai cara mengatasi ketika mengalami stressor. Sehingga membuat partisipan harus mencari pengganti untuk rokok.

Dalam penelitian ini, perasaan yang dirasakan oleh mantan perokok, sebagian besar dalam enam bulan pertama berhenti merokok. Setelah mantan perokok mampu mengatasi hambatan yang ada, maka 
mantan perokok mampu bertahan untuk berhenti merokok. Perasaan yang dirasakan oleh mantan perokok merupakan salah satu gejala dari aspek psikologis yang dirasakan oleh mantan perokok dalam penelitian ini.

Penelitian Giannakopoulos et al (2012), menjelaskan bahwa jika perokok berhenti merokok akan mengalami gejala-gejala seperti mudah tersinggung, gelisah, cemas, gugup. Gejala-gejala ini bisa terjadi setelah beberapa jam seseorang berhenti merokok, sehingga inilah yang menyebabkan seseorang kembali merokok dalam waktu singkat. Gejala-gejala ini mencapai puncaknya pada hari-hari awal ketika berhenti merokok, dan mungkin mereda dalam beberapa minggu. Namun bagi sebagian orang, gejala ini akan tetap bertahan selama berbulan-bulan.

Respon psikomotor juga ditemukan pada sebagian mantan perokok alami dalam usaha berhenti merokok. Perilaku ini teridentifikasi dari ungkapan bingung yang di alami oleh mantan perokok. Seperti " bingung karna biasanya pegang rokok" Dari ungkapan tersebut menunjukkan bahwa bingung dialami karena kebiasaan pegang rokok. Ungkapan lain "..... bingung gitu tu buk, tidak tau apa yang dikerjakan". Ungkapan tersebut menunjukkan bahwa mantan perokok mengalami bingung dan tidak tau apa yang harus di lakukan.

Perilaku yang di alami oleh mantan perokok berkaitan dengan kebiasaan yang di lakukan oleh mantan perokok selama merokok. Perilaku bingung bisa terlihat dari perilaku yang berusaha mencari kegiatan untuk mengganti kebiasaan. Berdasarkan wawancara pada mantan perokok, bingung akan kebiasaan pegang rokok, bisa di atasi dengan mencari alternatif lain seperti melakukan kegiatan dan mengkonsumsi permen. Dari kegiatan dan mengkonsumsi permen, bingung bisa diatasi.

2. Hambatan yang ditemukan dalam berhenti merokok

Penelitian ini berhasil menemukan dua hambatan besar yang dihadapi oleh para mantan perokok dalam upaya mereka berhenti merokok, yaitu faktor internal dan eksternal. Faktor internal lebih mengarah kepada faktor persona, dimana kebutuhan akan rokok diidentifkan dengan keinginan untuk bisa menemukan solusi terhadap sebuah masalah yang dihadapi. SEperti ungkapan yang disampaikan oleh partisipan sebagai berikut: "Lebih tenang tu merokok kalau lagi ada masalah". Dari ungkapan partisipan menunjukkan bahwa ketika partisipan memiliki masalah, maka memilih merokok untuk mengatasi masalah tersebut.

Selain itu merokok juga memberikan perasaan tenang. Hambatan dari faktor internal berikutnya adalah kebiasaan, dimana biasanya setelah makan, partisipan merokok untuk menghilangkan rasa yang tak enak setelah makan. Kedua hal ini menjadi hambatan terbesar, karena ketika para mantan perokok menghadapi masalah dan menginginkan solusi terhadap masalah, keinginan untuk kembali meroko menjadi muncul kembali.

Selain itu, hambatan faktor eksternal dari faktor teman sebaya juga menjadi hambatan yang sering ditemukan oleh mantan perokok. Faktor teman sebaya yang di alami oleh mantan perokok seperti melihat teman merokok, ajakan teman, di cela teman dan berkumpul dengan teman-teman.

Sebagian besar partisipan pada penelitian ini menyebutkan bahwa keinginan merokok muncul ketika partisipan berada dalam lingkungan perokok. Selain itu faktor teman sebaya mempersulit partisipan dalam usaha berhenti merokok. Hal lain yang dirasakan partisipan, ketika teman menawarkan rokok, ejekkan teman-teman yang disampaikan membuat tidak nyaman pada partisipan. Partisipan mulai belajar dari pengalamannya tersebut, dengan mengetahui bagaimana faktor dari luar mempengaruhinya untuk kembali merokok.

Salah satu mantan perokok dalam penelitian ini menjelaskan bahwa keberhasilan usaha berhenti merokok sangat dipengaruhi oleh pergaulan sosial, seperti berkumpul dan hajatan dilingkungan. Merokok menjadi sesuatu yang dapat diterima oleh masyarakat. Sehingga ketika mantan perokok berada dilingkungan sosial, menjadi sulit yang dirasakan oleh partisipan.Sejalan dengan penelitian Ellizabet (2010), mengungkapkan bahwa faktor terbesar seseorang merokok adalah faktor social dan lingkungan, sebagai upaya untuk menyesuaikan diri. Merokok dianggap sebagai cara untuk bisa diterima secara sosial.

Faktor teman sebaya yang tidak terlepas dari rokok, membuat partisipan kesulitan untuk berhenti merokok, karena merokok di anggap bentuk menyesuikan diri terhadap lingkungan. Namun pada penelitian ini membuktikan bahwa partisipan berhasil berhenti merokok dengan melakukan cara menghindari pergaulan merokok dan mencari kesibukan. Partisipan telah melakukan berbagai cara untuk berhenti merokok. Cara yang dapat dilakukan oleh mantan perokok, dalam penelitian ini dijelaskan pada koping yang digunakan oleh mantan perokok.

3. Mekanisme yang digunakan

Mekanisme koping adalah upaya atau cara yang dilakukan individu terhadap perubahan 
lingkungan maupun masalah atau kondisi tertentu. Mekanisme koping terbagi atas koping adaptif dan koping maladaptif (Stuart , 2013). Mekanisme koping yang digunakan padalam penelitian ini adalah koping adaptif dan koping maladaptif. Koping adaptif yang ditemukan adalah melakukan kegiatan dan menghindari orang yang merokok. Sedangkan koping maladaptif ditemukan adalah membeli rokok, mengkonsumsi permen, makan makanan ringan, kembali merokok.

Cara yang paling sering dilakukan oleh sebagian besar mantan perokok adalah mengkonsumsi permen. Seperti ungkapan "kalau keingat-ingat rokok, makan aja permen lagi". Dari ungkapan tersebut menunjukkan bahwa kebiasaan akan merokok bisa digantikan dengan mengkonsumsi permen. Mantan perokok menyatakan bahwa mengkonsumsi permen sebagai pengganti dari merokok, karena kebiasaan merokok dijadikan sebagai aktifitas mengisi waktu dan mengatasi masalah.

Dalam usaha berhenti merokok dibutuhkan alternatif pengganti rokok, yaitu mengkonsumsi perment. Ketika timbul keinginan untuk merokok, mantan perokok mengkonsumsi permen untuk mengalihkan keinginan merokok tersebut sehingga berhasil dalam berhenti merokok. Partisipan mengatakan, kebiasaan yang ditimbulkan oleh rokok membuat partisipan berinisiatif mengkonsumsi permen sebagai penganti rokok. Alternatif mengganti rokok dengan permen ternyata mampu mengalihkan ingatan mantan perokok terhadap rokok.

Penelitian Meldy (2016) menyatakan bahwa perokok bisa mengkonsumsi permen ketika bosan. Sehingga dengan mengunyah permen dapat membantu perokok untuk mengurangi keinginan merokoknya. Hal ini juga didukung oleh penelitian Salika (2010) yang menyatakan perokok dapat mengantikan rokok dengan mengunyah permen, sehingga pikiran perokok bisa dialihkan dari rokok.

Selain mengkonsumsi permen, dalam penelitian ini partisipan juga makan makanan ringan. Seperti "Pokoknya sering juga diganti dengan cemil-cemilan". Dari ungkapan tersebut menunjukkan bahwa alternatif yang bisa menggantikan rokok adalah makan makanan ringan. Makanan ringan mampu membantu mantan perokok melawan keinginan merokok. Hal ini dirasakan, karena bagi mantan perokok, aktifitas mengunyah di mulut mampu mengalihkan keinginan mantan perokok untuk merokok. Mantan perokok juga menyatakan, hal ini dapat membantu dalam usaha berhenti merokok. Walaupun mantan perokok mengalami dampak terhadap fisiologis, seperti peningkatan berat badan.

Penelitian Partoba (2012) menyatakan salah satu faktor yang membuat orang ketagihan merokok adalah kebiasaan menaruh sesuatu di mulut. Perokok bisa mengganti kebiasaan ini dengan menaruh sesuatu yang bisa dimakan dan ditelan. Kebiasaan menaruh sesuatu di mulut dapat membantu partisipan mengalihkan perasaan ingin merokok.

Sebelum keberhasilan menghentikan merokok, usaha mantan perokok dalam berhenti merokok, tidak begitu mudah dihadapi. Pada penelitian ini, sebagian besar mantan perokok menjelaskan bahwa dalam usaha berhenti merokok dilakukan berulang-ulang kali atau mengalami kekambuhan. Hal ini terjadi pada beberapa minggu pertama usaha berhenti merokok, karena tidak mampu menghadapi hambatan yang di alami.

Dalam beberapa bulan pertama sangat rentan mantan perokok mengalami kekambuhan. Selain karena faktor kebiasaan yang sulit dihilangkan oleh mantan perokok, namun juga pengaruh nikotin yang membuat ketergantungan akan rokok. Dalam penelitian ini mantan perokok menjelaskan, kekambuhan terjadi karena rendahnya motivasi untuk berhenti merokok. Kenikmatan dan kecanduan merokok dapat mengindahkan kekawatiran dari efek merokok terhadap kesehatan, dan keluarga.

Diperkuat oleh penelitian Hughes (2014) mengatakan bahwa kekambuhan tertinggi tertinggi terjadi dalam beberapa minggu pertama, diantaranya $95 \%$ dari mantan perokok gagal dalam mempertahankan untuk tidak merokok yang terjadi dalam waktu satu tahun pertama. Kendatipun demikian, usaha untuk berhenti merokok tetap dilakukan. Dalam penelitian ini pada sebagian besar mantan perokok menjelaskan bahwa tidak lagi memiliki keinginan untuk kembali merokok. Namun sebagian kecil juga ditemukan memiliki keinginan untuk kembali merokok, karena telah mamiliki niat yang kuat dan kesadaran diri untuk merubah perilaku. Serta diperlukan upaya yang dilakukan sehingga keinginan untuk tidak merokok tercapai.

4. Motivasi dalam berhenti merokok

Motivasi sangat erat kaitannya dengan keberhasilan mantan perokok dalam usaha berhenti merokok. Motivasi yang mendasari partisipan untuk berhenti merokok. Motivasi terdiri dari motivasi intrinsik dan motivasi ekstrinsik. Motivasi intrinsik yang teridentifikasi dalam penelitian ini adalah niat yang kuat dan kesadaran diri. Sedangkan motivasi ekstrinsik terdintifikasi dari keluarga, kesehatan dan finansial.

Berdasarkan ungkapan partisipan yang mengatakan bahwa, seperti ungkapan "...tergantung niat sebenarnya orang yang berenti merokok tu". Dari ungkapan tersebut menunjukkan, bahwa dengan adanya niat yang kuat, mantan perokok bisa mengatasi hambatan yang di alami. Selain itu juga dibutuhkan 
motivasi ektrinsik. Niat yang kuat sangat diperlukan dalam usaha berhenti merokok. Niat yang kuat datang dari dalam diri, sangat mempengaruhi terhadap keberhasilan berhenti merokok. Rodenstock (2013) menyatakan bahwa perilaku individu ditentukan oleh motif dan kepercayaannya, tanpa memperdulikan apakah motif dan kepercayaan tersebut sesuai atau tidak dengan pandangan orang lain tentang apa yang baik untuk individu tersebut.

Sebahagian besar partisipan mengungkapkan, bahwa adanya niat yang kuat bisa bertahan untuk tidak merokok. Sesuai dengan penelitan Rosita (2012), yang mengatakan bahwa keberhasilan seseorang dalam usahanya untuk berhenti merokok ditentukan oleh sejauh mana niatnya untuk berhenti merokok. Selain itu Triswanto (2007), menyebutkan bahwa sesungguhnya partisipan masih bisa kembali merokok, namun karena partisipan memiliki niat yang kuat untuk tidak kembali merokok, maka usaha berhenti merokok berhasil dilakukan.

Penelitian Wulandari dan Santoso (2012) menyebutkan bahwa cara yang dilakukan dalam usaha berhenti merokok dengan berkomitmen dan niat. Hasil pada penelitian ini juga mengatakan bahwa bagi partisipan dengan berkomitmen dan memiliki niat kuat, partisipan berhasil untuk berhenti merokok. Hal itu membantu partisipan untuk mencoba bertahan untuk berhenti merokok demi orang-orang yang dicintai.

Usaha berhenti merokok tanpa adanya niat yang kuat, besar kemungkinan bagi perokok untuk kembali merokok. Partisipan menunjukkan bahwa keberhasilan seseorang dalam usahanya untuk tidak merokok ditentukan oleh sejauh mana komitmennya untuk berhenti merokok. Dengan berkomitmen terhadap diri sendiri akan menguatkan partisipan untuk mengontrol perilakunya terhadap rokok dalam kondisi apapun.

Berdasarkan ungkapan partisipan pada penelitian ini, peneliti menyimpulkan bahwa motivasi internal merupakan modal yang kuat dari dalam diri partisipan untuk berhenti merokok. Selain dari mekanisme koping yang digunakan dan motivasi eksternal yang dimiliki, dibutuhkan niat yang kuat untuk berhenti merokok.

Motivasi internal pada penelitian ini juga teridentifikasi kesadaran diri. Partisipan mengungkapkan kesadaran diri timbul setelah memiliki niat untuk berhenti merokok. Seperti "...tu adalah suatu hikmah dari kejadian itu, timbul kesadaran untuk berhenti. niat sudah kuat dan lalu kesadaran timbul". Ungkapan tersebut menunjukkan kesadaran diri muncul, karena dampak dari rokok yang dihadapi oleh partisipan.

Kesadaran diri (self awareness) untuk berhenti merokok pada partisipan dipengaruhi oleh dampak yang dialami partisipan selama merokok. Partisipan mengungkapkan bahwa berbagai penyakit telah dialami selama merokok. Selain itu partisipan juga mengungkapkan rokok tidak hanya memiliki dampak buruk bagi kesehatan, tetapi juga pada finansial. Penelitian Hendriani (2012) menyebutkan bahwa sebanyak $76 \%$ partisipan berhenti merokok karena kesadaran sendiri. Hal ini juga didukung oleh penelitan (Syafiie, Frienda \& kahija, 2009) yang menyebutkan, bahwa dalam proses peningkatan kesadaran diri diperlukan proses kognisi yang dinamis berupa pengetahuan, perubahan persepsi terkait rokok dan evaluasi menimbang kerugian merokok.

Aldiabat \& Clinton (2012), menyatakan bahwa dalam proses peningkatan kesadaran diri (self awareness) sebelum dapat berhenti merokok, diperlukan sebuah proses kognisi yang dinamis. Berupa penambahan pengetahuan atau pemahaman, perubahan persepsi (dapat berkaitan dengan mitos seputar rokok), evaluasi menimbang kerugian merokok dan keuntungan berhenti merokok dan lain sebagainya, perubahan idealisme (memilih yang terbaik) dan lain sebagainya. Perubahan pengetahuan disini adalah pengetahuan yang memiliki argumen yang kuat agar dapat menimbulkan kesadaran.

Pada penelitian ini muncul kesadaran diri disebkan karena mantan perokok mengalami kejadian tertentu. Saat partisipan mendapatkan hikmah dari kejadian tersebut, partisipan memutuskan untuk berhenti merokok dengan memiliki niat yang kuat, kemudian timbul kesadaran diri untuk berhenti merokok.

Motivasi selanjutnya adalah motivasi eksternal, yang teridentifikasi dari keluarga, kesehatan dan fianansial. Motivasi dari keluarga ditemukan pada sebagian besar partisipan. Dalam penelitian ini, motivasi keluarga teridentifikasi dari istri dan dampak yang ditimbulkan terhadap anak. Partisipan mengungkapkan bahwa motivasi dari istri bisa memotivasi partisipan untuk berhenti merokok "berkat motivasi istri akhirnya berhenti total". Ungkapan partisipan menunjukkan bahwa keluarga bisa mendorong partisipan untuk menghentikan kebiasaan merokok.

Motivasi keluarga juga datang dari anak. Ini berupa ungkapan kekawatiran yang dirasakan oleh mantan perokok akan bahaya rokok terhadap keluarga terdekat. Ungkapan mantan perokok menunjukkan 
bahwa perilaku merokok juga mengakibatkan dampak buruk dari paparan asap rokok terhadapa keluarga. Selain itu, partisipan termotivasi berhenti merokok, karena perilaku merokok juga bisa ditiru oleh anak dari partisipan. Selain itu, dalam penelitian ini mantan perokok juga menjelaskan bahwa paparan asap rokok bisa berdampak buruk bagi anak-anak mereka. Hal ini juga menjadi motivasi bagi mantan perokok untuk behenti merokok.

Penelitian Tulloch et al (2016), menemukan dukungan keluarga/ sosial ditemukan $(28,1 \%)$. Sedangkan penelitian Butler (2015) menemukan bahwa perhatian terhadap anak-anak sebagai motivator untuk berhenti merokok. Pada penelitian ini menjelaskan keinginan mantan perokok untuk melindungi anak-anak dari penggunaan rokok. Dalam penelitian ini, keluarga menjadi motivator yang cukup kuat, karena mantan perokok merasakan perasaan bersalah dan tekanan untuk berhenti merokok. Selain itu, Motivasi dari keluarga yang meminta partisipan untuk tidak kembali merokok demi menjaga kesehatan diri dan keluarga.

Penelitian Wulandari dan Santoso (2012) bahwa keluarga, saudara, dan teman yang anti dengan asap rokok dapat menjadi motivasi yang kuat berhenti merokok. Selain itu, penelitian Partoba (2012) juga menyatakan bahwa untuk berhenti merokok, dibutuhkan motivasi dari keluarga dan lingkungan. Hasil penelitian Wulandari dan Santoso (2012) menyimpulkan bahwa mantan perokok yang telah berhenti merokok juga membutuhkan dukungan dari orang terdekat.

Merubah perilaku merokok tidak hanya mengatasi faktor internal dan faktor eksternal, tetapi juga dibutuhkan motivasi dari dalam diri maupun luar, sehingga bisa merubah perilaku merokok dari partisipan. Sejalan dengan penelitian Meyer (2015) menemukan bahwa untuk berhenti merokok diperlukan adanya motivasi dari keluarga dan dukungan dari teman sebaya mantan perokok serta alasan kesehatan. Faktor tersebut dapat memberikan makna dalam memotivasi perokok untuk mempertimbangkan berhenti merokok.

Dampak kesehatan karena rokok juga memicu keinginan untuk berhenti merokok, demi kesehatan diri, yang menjadi motivasi ekstrinsik dalam penelitian ini. Motivasi menjaga kesehatan sebagian besar dimiliki oleh partisipan. Selain memiliki niat yang kuat, menjaga kesehatan juga sangat berperan penting dalam berhenti merokok. Partisipan yang memiliki motivasi akan menjga kesehatan timbul, karena sebagian partisipan memiliki pengetahuan akan bahaya yang ditimbulkan dari merokok. seperti ungkapan “..... berhenti merokok karena dalam keadaan sakit batuk. Tertarik berhenti juga karena tau akan bahaya rokok bagi kesehatan”. Dari ungkapan partisipan tersebut menunjukkan bahwa penyakit yang ditimbulkan dari merokok bisa memotivasi partisipan untuk berhenti merokok.

Penelitian Butler et all (2015) menyatakan penyakit kronis bisa menjadi motivator untuk berhenti merokok sekaligus stressor yang bisa menghalangi pikiran untuk merokok. Dalam rokok tersebut terkandung lebih dari 4000 jenis bahan kimia berbahaya bagi kesehatan, mulai dari nikotin maupun zat lainnya yang bisa menyebabkan kanker dan zat beracun bagi tubuh lainnya. Bahaya merokok bagi kesehatan bukan saja bagi perokok tetapi bagi orang sekitar karena efek asap rokok atau perokok pasif. Orang-orang yang merokok mereka belum mengetahui tentang pengertian kesehatan sesungguhnya (Kementrian kesehatan, 2017).

Penyakit berbahaya yang diakibatkan oleh rokok, adalah Penyakit paru-paru. Asap rokok tersebut terhirup dan masuk ke dalam paru-paru sehingga menyebabkan paru-paru mengalami radang, bronchitis, pneumonia. Selain itu bahaya dari zat nikotin yang menyebabkan kerusakan sel-sel dalam organ paruparu yang bisa berakibat fatal yaitu kanker paru-paru. Penyakit kanker paru-paru merupakan salah satu penyakit yang sangat di takutkan oleh salah satu partisipan (Kementrian kesehatan, 2017).

Efek bahaya merokok bagi kesehatan lainnya adalah bisa mengakibatkan impotensi. kasus seperti ini sudah banyak dialami oleh para perokok. Sebab kandungan bahan kimia yang sifatnya beracun tersebut bisa mengurangi produksi sperma pada pria. Efek selanjunya adalah penyakit lambung. Menghisap rokok adalah aktifitas otot di bawah kerongkongan semakin meningkat. Otot sekitar saluran pernafasan bagian bawah akan lemah secara perlahan sehingga proses pencernaan menjadi terhambat (Kementrian kesehatan, 2017).

Penelitian Tulloch et al (2016) menemukan bahwa motivasi akan menjaga kesehatan sebanyak (91\%). Kesehatan merupakan motivasi yang paling umum ditemukan pada mantan perokok untuk berhasil dalam usaha berhenti merokok.

Selanjutnya finansial yang merupakan motivasi yang ditemukan pada sebagian kecil pada penelitian ini. Finansial diungkapkan oleh partisipan sebagai motivasi pendukung, seperti jadi banyak "...keuntungannya tidak merokok, uang jadi tersimpan". Dari ungkapan tersebut menunjukkan bahwa dengan berhenti merokok, partisipan bisa menyimpan uang. Selain itu, mahalnya harga rokok tentu saja akan mempengaruhi ekonomi partisipan, seperti "...dari situ saya berfikir, coba dari muda saya berhenti merokok. Bukan sudah berkeluarga, jadi bisa tersimpan uang". Ungkapan tersebut menunjukkan, bila 
semenjak dahulu berhenti merokok, maka uang yang dibelikan untuk membeli rokok sudah tersimpan lebih banyak.

Setelah berhenti merokok partisipan merasakan manfaat yang besar terhadap kesehatan dan finansial. Partisipan mengatakan bahwa uang yang seharusnya untuk membeli rokok bisa kumpulkan untuk berbagai kebutuhan keluarga. Selain itu, finansial merupakan salah satu indikasi partisipan untuk berhenti merokok. Menurut Satiti (2012) menyebutkan bahwa seseorang perokok tidak memikirkan besarnya uang yang harus dibelanjakan untuk rokok, padahal dana yang dibelanjakan untuk rokok relative besar (Santoso, 2012).

Pada penelitian ini, partisipan menyadari akan dampak merokok setelah merasakan berbagai dampak kesehatan dan fianansial. Walaupun partisipan terlambat menyadari bahaya rokok tersebut, partisipan merasakan banyak manfaat yang dirasakan setelah berhenti merokok.

\section{Perubahan Fisiologis berhenti merokok}

Perubahan fisiologis (sistem pencernaan dan sistem pernafasan) merupakan dampak yang ditimbulkan dalam usaha berhenti merokokPerubahan pada pencernaan teridentifikasi dari ungkapan nafsu makan meningkat dan berat badan meningkat. Sedangkan perubahan pada pernafasan yang teridentifikasi dalam penelitian ini adalah pernafasan membaik, kondisi batuk membaik bau terhadap asap rokok

Perubahan yang terjadi pada partisipan dalam penelitian ini, merupakan perubahan yang di alami pada sebagian besar partisipan setelah berhenti merokok. Perubahan yang terjadi nafsu makan meningkat, karena partisipan berhenti merokok terjadi peningkatan nafsu makan seperti ungkapan partisipan kedua "..... Iya tambah enak makan ", dan yang dialami oleh partisipan kelima, karena sering makan makanan ringan, seperti“....Banyak makan makanan ringan. ngemil badan naik, berat badan bertambah, nafsu makan bertambah". Ungkapan partisipan tersebut menunjukkan bahwa adanya perubahan yang terjadi pada fisik partisipan yang menunjukkan peningkatan. Ini juga di nyatakan oleh partisipan kedua bahwa terlihat lebih gemuk dan terjadi peningkatan berat badan.

Partisipan menyatakan bahwa setelah berhenti merokok banyak perubahan yang dialaminya terutama perubahan fisik. Selain porsi makan yang besar, partisipan keempat bisa menikmati makanan dan semua makanan terasa semakin enak, sehingga porsi makannya pun besar. Partisipan juga juga tidak merasa sakit-sakitan dan dia merasa lebih sehat dari sebelumnya.

Sejalan dengan penelitian Fauzani (2005), pada sebagian besar pada partisipan mengakui bahwa banyak terjadi parubahan yang di alami, terutama perubahan fisik. Pada penelitian ini, partisipan mengatakan bahwa terjadinya peningkatan berat badan dikarenakan banyak makan makanan ringan. Terjadinya berat badan meningkat karena porsi makan yang lebih banyak dibandingkan sebelum berhenti merokok. Hal ini terkait karena meningkatnya nafsu makan. Selain itu, partisipan mengatakan bahwa, lebih menikmati makanan dan merasa lebih sehat setelah berhenti merokok.

\section{KESIMPULAN}

Berhenti merokok bukanlah hal yang mudah, dikarenakan merokok merupakan suatu perilaku kebiasaan yang sulit di hilangkan. Dalam usaha berhenti merokok pada penelitian ini, untuk sampai berhenti merokok, mantan perokok tidak dengan cepat mengalami tahap keberhasilan. Partisipan dalam beberapa bulan pertama dalam usaha berhenti merokok, mengalami respon, dalam penelitian ini yang teridentifikasi adalah respon afektif, kognitif dan perilaku. Dalam upaya berhenti merokok, hambatan terbesar yang dirasakan adalah adanya keinginan untuk kembali merokok karena faktor kebiasaan dan persepsi bahwa merokok memberikan ketenangan. Selain itu faktor teman sebaya dan lingkungan menjadi aspek utama yang menjadi hambatan. Namun, motivasi yang ada dalam diri dan berasal dari lingkungan menjadi daya pendorong utama dalam berhenti merokok. Kegiatan berhenti merokok menghasilkan perubahan kearah yang lebih baik untuk fisiologis partisipan.

\section{DAFTAR PUSTAKA}

Aldiabat, K., \& Clinton, M. (2012). Contextualizing Smoking Behaviour over Time : A Smoking Journey from Pleasuring to Suffering, 3(January), 1-19

Ellizabet, Lisa. (2010), Stop merokok. Yogyakarta: Garailmu.

Fawzani, Nurdidayati (2005), Terapi berhenti Merokok (Studi Kasus 3 perokok berat), Makara Kesehatan Vol 9, No. 1 15-21

Giannakopoulos, G., Tzavara, C., Dimitrakaki, C., Kolaitis, G., \& Rotsika, V. (2012). Emotional , behavioural problems and cigarette smoking in adolescence : findings of a Greek cross-sectional study. 
Procedia - Social and Behavioral Sciences, 1-12.

Hughes, J. R. (n.d.). Motivating and Helping Smokers to Stop Smoking, 1419, 1053-1057.

Khattab, Adel Mahmoud a ., Eman Badawy AbdelFattah a ., A. K. E. (2016). Study of smoking habit among soldiers in Cairo. Asmaa Khairy Eldien Awad Abozahra. 26(1), 204-216.

Lee, P. N., Oxon, M., Thornton, A. J., Forey, B. A., \& Hamling, J. S. (2017). Environmental Tobacco Smoke Exposure and Risk of Stroke in Never Smokers: An Updated Review with Meta-Analysis. Journal of Stroke and Cerebrovascular Diseases, 26(1), 204-216.

Meldy. 2016. Inilah Yang Harus Dikosumsi Untuk Mengurangi Kecanduan Rokok. Kompas. http://www.kompasiana.com

Meyer MG, Toborg MA, Denham SA, et al. Cultural perspectives concerning adolescent use of tobacco and alcohol in the Appalachian mountain region.J Rural Health 2008;24(1):67-74.

Kementrian Kesehatan RI, (2013), Riset Kesehatan Dasar . http//www.google.com/search/riskesdas2013.

Kementrian Kesehatan RI, (2007), Riset Kesehatan Dasar . http//www.google.com/search/riskesdas2013.

Rosita, R., Suswardany, D,L., \& Abidin, Z. 2012. Penentu Keberhasilan Berhenti Merokok Pada Mahasiswa. Jurnal Kesehatan Masyarakat Vol.1-13

Sallika. 2010. Serba-serbi kesehatan perempuan. Jakarta: Bukune.

Siriwong, S. (2015). Exploring Quitting Smoking Behavior Among Royal Thai Navy Personnel With The Transtheoretical Model. Procedia - Social and Behavioral Sciences, 191, 1062-1068.

Stuart, G.W. (2013). Prinsip dan Praktik Keperawatan Kesehatan Jiwa ed Indonesia. (ed, Ed.). Jakarta, Indonesia: Fakultas Keperawatan Indonesia.

Syafie R. dkk. 2009. Stop smoking : studi kualitatif terhadap pengalaman mantan pecandu rokok dalam menghentikan kebiasaannya. Semarang: Universitas Diponegoro

Tombor, I., Shahab, L., Brown, J., Notley, C., \& West, R. (2015). Addictive Behaviors Does non-smoker identity following quitting predict long-term abstinence? Evidence from a population survey in England. Addictive Behaviors, 45, 99-103.

Triswanto, S. D. (2007). Stop Smoking, Jakarta: Books, Ed.

Tulloch, H. E., Psych, C., Pipe, A. L., Clyde, M. J., Reid, R. D., \& Els, C. (2016). The Quit Experience and Concerns of Smokers With Psychiatric Illness. American Journal of Preventive Medicine, 50(6), 709-718.

Yingying, W., Zhao, L., Ou, Z., Min, C., Lingling, H., Yuan, W., Xiuq-, H. (2016). Clinical Study Effect of acupuncture treatment on smoking cessation in smokers from Hong Kong. Journal of Traditional Chinese Medicine, 36(5), 634-639. 